\title{
BUDAYA KESELAMATAN PASIEN PADA PERAWAT DI INSTALASI PERAWATAN INTENSIVE RSUD ARIFIN ACHMAD PROVINSI RIAU
}

\author{
Yeni Yarnita ${ }^{1}$; Maswarni ${ }^{2}$ \\ 1,2 Program Studi DIII Keperawatan, FMIPA dan Kesehatan, \\ Universitas Muhammadiyah Riau, Indonesia \\ Email:yeniyarnita@umri.ac.id; maswarni@umri.ac.id
}

\begin{abstract}
Adverse events can be minimized the level of madness in the hospital by proclaiming behaviors that encourage the formation of patient safety known as the patient safety culture. Various health services, especially hospitals, data on Adverse events are still found annually. This study aims to determine the description of patient safety culture at nurses at the Intensive Care Installation Arifin Achmad Hospital of Riau. The population was all nurses in the Intensive Care Installation Arifin Achmad Hospital of Riau. This research is descriptive research with quantitative approach the data analysis done is descriptive statistic processing data the spss program with size are 64 nurses with total sampling techniques in accordance with the inclusion and exclusion criteria. Data collection used a questionnaire adopted from Hospital Survey on Patient Safety (HSPSC) questionnaire published by The Agency For Healthcare Research and Quality (AHRQ). The results of the study prove that $56.3 \%$ of the patient's safety culture is negative category, and $43.8 \%$ of the patient's safety culture is positive category, importance to make programs that are related to patient safety culture are was need to improve the patient safety culture in Arifin Achmad Hospital of Riau.
\end{abstract}

\section{Keywords : Safety Culture; Nurses; Intensive}

\section{PENDAHULUAN}

Rumah sakit merupakan suatu wadah pelayanan kesehatan yang utama. Dengan demikian rumah sakit harus mampu memberikan pelayanan kesehatan yang terintegrasi pada pasien sebagai penguna layanan. Membangun gerakan keselamatan pasien di rumah sakit merupakan prioritas utama pada layanan rumah sakit. akan menguntungkan berbagai pihak baik itu rumah sakit maupun pasien sebagai pengguna layanan kesehatan (KKPRS, 2015)

Data tentang keselamatan pasien di dunia masih menunjukkan masalah dalam dunia kesehatan. Institute of Medicine (IOM) pada tahun 2008 melaporkan angka Kejadian Tidak Diharapkan (KTD) pada rumah sakit di Amerika Serikat yaitu 1.5 juta pasien terluka pertahun dari kesalahan pengobatan, dan 7000 diantaranya dilaporkan meninggal (Webair et al., 2015). Selain itu berdasarkan hasil penelitian di negara Arab 2,5\% juta sampai $18 \%$ KTD terjadi pada pasien, dari data tersebut $83 \%$ kejadian memiliki efek samping resiko kematian (Najjar, Nafouri, Vanhaecht, \& Euwema, 2015a) 
Data yang cukup besar juga ditunjukkan oleh lembaga-lembaga kesehatan dunia dimana terdapat sebagian besar kejadian kesalahan medis serta masalah dalam perawatan pasien(Aspend, 2017). Data di Amerika memperlihatkan bahwa 1.5 juta orang terluka setiap tahunnya dan rata-rata pasien yang di rawat inap mengalami satu kesalahan setiap harinya. mengalami memperkirakan rata-rata $10 \%$ dari semua kunjungan rawat inap menimbulkan beberapa bentuk bahaya yang tidak diinginkan, laporan dari negara-negara berkembang juga menunjukkan angka 77\% pada kasus KTD(Aspend, 2017)

Sistem budaya keselamatan yang terdapat dalam organisasi dapat bersifat positif dengan adanya komunikasi terbuka yang berdasarkan nilai-nilai organisasi dan kepercayaan serta adanya persepsi yang didukung oleh anggota organisasi atau individu dalam suatu organisasi (Hammer et al., 2011)

Rumah Sakit Umum Daerah Provinsi Riau adalah rumah sakit pemerintah tipe B pendidikan dan merupakan rumah sakit rujukan utama di Provinsi Riau. Kinerja pelayanan RSUD Arifin Achmad Provinsi Riau dimana BOR pada tahun 2013 mencapai $72.58 \%$.

Berdasarkan permenkes No 129/ Th. 2008 tentang Standar Pelayanan Minimal (SPM) Rumah Sakit menujukkan bahwa SPM ruang Rawat Inap yang berkaitan dengan pasien jatuh harus menunjukkan angka nol atau pada nilai "zerro defect" (tingkat insidensi $0 \%$ ) dalam tiap tahunnya

\section{METODE}

Penelitian ini merupakan penelitian deskriprif yang akan menggambarkan distribusi dan frekuesi budaya keselamatan pasien pada perawat di Intalasi Perawatan Intensive. Populasi dalam penelitian ini adalah seluruh perawat pelaksana yang bekerja di Instalasi Perawatan Intensive RSUD Arifin Achmad Provinsi Riau dengan jumlah sampel 64 orang dengan teknik pengambilan sampel total saplling atau sampel jenuh menggunakan kriteria inklusi dan eklusi.

Penelitian dimulai dengan melakukan ethical clearance yang selanjutnya dilakukan penelitian pada bulan Mei sampai dengan Juni 2019. Alat Pengumpulan data menggunakan kuesioner yang diadopsi dari kuesioner Hospital Survey On Patient Safety (HSPSC) yang akan mengukur 12 dimensi budaya keselamatan pasien di rumah sakit yang dipublikasikan oleh The Agency For Healthcare Research and Quality (AHRQ, 2016) untuk mengukur 12 dimensi budaya keselamatan pasien di rumah sakit. Analisa data menggunakan program SPSS yang disajikan dalam bentuk distribusi 
frekuensi untuk melihat frekuensi karakteristik responden berdasarkan umur, jenis kelamin, pendidikan, lama kerja, budaya keselamatan pasien dan dimensi budaya keselamatan pasien di Instalasi Perawatan Intensive RSUD Arifin Achmad Provinsi Riau.

\section{HASIL DAN PEMBAHASAN}

\section{Hasil}

\section{Karakteristik Responden}

Distribusi karakteristik perawat pelaksana di Instalasi Perawatan Intensive RSUD Arifin Achmad Provinsi Riau dapat di lihat pada table sebagai berikut:

Table 1.

Karakteristik Perawat Pelaksana di Instalasi Perawat $(n=64)$

\begin{tabular}{|c|c|c|c|}
\hline No & Karakteristik & $f$ & $\%$ \\
\hline \multirow[t]{4}{*}{1.} & Usia & & \\
\hline & a. $26-35$ tahun & 28 & 43.8 \\
\hline & b. $36-45$ tahun & 34 & 53.1 \\
\hline & c. $45-55$ tahun & 2 & 3.1 \\
\hline \multirow[t]{3}{*}{2.} & Jenis kelamin & & \\
\hline & a. Perempuan & 55 & 85.9 \\
\hline & b. laki-laki & 5 & 14.1 \\
\hline \multirow[t]{3}{*}{3.} & Tingkat Pendidikan & & \\
\hline & a. D III & 44 & 68.8 \\
\hline & $\begin{array}{l}\text { b. S1 Keperawatan/ } \\
\text { c. Ners }\end{array}$ & 20 & 32.2 \\
\hline \multirow[t]{4}{*}{4.} & Lama Kerja & & \\
\hline & a. $<5$ Tahun & 11 & 17.3 \\
\hline & b. $\geq 5$ tahun & 53 & 82.8 \\
\hline & Total & 64 & 100 \\
\hline
\end{tabular}

Hasil penelitian memperlihatkan usia responden lebih banyak terdapat pada kelompok usia 36 - 45 tahun yaitu 53.1\%. (Najihah, 2018) mengatakan bahwa sikap perawat pada kelompok usia dewasa akhir berkaitan dengan penerapan budaya keselamatan pasien. Hal ini disebabkan oleh pertambahan umur individu akan menyebabkan variasi kegiatan, perasaan, sehinggan meningkatkan kebutuhan individu yang akan mempengaruhi dalam melakukan pekerjaan sehari-hari.

Sedangkan untuk jenis kelamin responden dalam penelitian ini lebih banyak berjenis kelamin perempuan yaitu sebesar $85.9 \%$ dengan Karakteristik responden berdasarkan tingkat pendidikan adalah $68.8 \%$ perawat memiliki pendidikan D III Keperawatan serta $82.8 \%$ perawat memiliki masa kerja lebih dari $\geq 5$ tahun.

\section{Berdasarkan Undang-Undang} keperawatan no 38 tahun 2014 DIII keperawatan merupakan tingkat pendidikan keperwatan terendah yang dikenal dengan istilah perawat vakasional dengan tugas dan tangung jawab pemberi pelayanan langsung dibawah superfisi dan dengan batsan tertentu.

Hal ini jauh berbeda dengan perawat dengan tingkat pendidikan S1 keperawatan yang dikenal dengan istilah perawat profesional dengan tugas dan tangungjawab memberikan 
pelayanan keperawatan secara

mendiri, otonom dan mampu berkolaborasi dengan tenaga kesehatan yang lain.

Adanya sistem yang baik dibagun oleh sebuah organisasi namun jika tidak didukung oleh nilai-nilai budaya seperti kompetensi individu maka angka KTD tetap terjadi (Budihardjo, 2008). Tingkat pendidikan merupakan pengalaman yang berfungsi mengembangkan kemampuan dan kualitas kepribadian seseorang, dimana semakin tinggi tingkat pendidikan semakin besar untuk memanfaatkan pengetahuan dan keterampilan. Tingkat pendidikan yang lebih tinggi biasanya menyebabkan seseorang lebih mampu dan bersedia menerima posisi dan tanggungjawabnya (Anwar, 2018).

Selain itu Menurut Cox, et al., (2006) dalam (Anwar, 2018) Semakin lama bekerja, keterampilan dan pengetahuan akan meningkat dan memperoleh pekerjaan yang lebih matang, juga akan merasa mempunyai peluang untuk memperoleh pengakuan dan penghargaan hal ini akan mempermudah mendapatkan pekerjaan dan kepercayaan atau wewenang, sehingga mereka akan puas dan mempunyai komitmen yang tinggi dalam menjalankan aktivitas sehari-hari.

\section{Budaya Keselamatan Pasien}

Distribusi budaya keselamatan pasien di ruang Instalasi Perawatan Intensive RSUD Arifin Achmad Provinsi Riau sebagai berikut:

Tabel 2.

Distribusi Frekuensi Budaya Keselamatan Pasien $(n=64)$

\begin{tabular}{clcc}
\hline No & Variabel & $\boldsymbol{f}$ & $\boldsymbol{\%}$ \\
\hline 1 & Negatif & 36 & 56.3 \\
2 & Positif & 28 & 43.8 \\
& Total & 64 & 100 \\
\hline
\end{tabular}

Berdasarkan tabel 2 diatas, dapat dilihat bahwa lebih dari separuh perawat memiliki budaya keselamatan negatif yaitu $36(56.3 \%)$. Hasil penelitian ini menunjukkan bahwa lebih banyak perawat yang memiliki nilai-nilai, kompetensi, sikap serta pola perilaku keselamatan pasien yang masih belum sesuai dengan yang diharapkan dalam budaya keselamatan pasien. Hal ini tentunya bertolak belakang dengan budaya keselamatan pasien yang diharapkan di rumah sakit.

Budaya keselamatan yang ditandai dengan adanya alur informasi yang baik dan adanya proses komunikasi yang berkaitan dengan pembelajaran pada saat KTD, memiliki pemimpin yang komit dan eksekutif yang bertanggung jawab serta pendekatan untuk tidak menyalahkan dan tidak memberikan hukuman pada insiden yang dilaporkan 
merupakan budaya penting yang harus dibangun pada sebuah rumah sakit.

Hasil penelitian didukung oleh penelitian Nurmalia (2013) tentang pengaruh program mentoring terhadap penerapan budaya keselamatan pasien didapat $52.2 \%$ perawat memiliki budaya keselamatan negatif dan $47.3 \%$ perawat memiliki budaya keselamatan positif. Sejalan dengan Penelitian Nivalinda, Hartini dan Santoso (2013) diperoleh hasil $51.4 \%$ perawat memiliki budaya keselamatan pasien negatif.

Budaya keselamatan pasien merupakan kewajiban dan tanggung jawab seluruh pegawai. Pengawai adalah bagian dari organisasi merupakan ujung tombak dalam budaya keselamatan pasien (Amarapathy, Sridharan, Perera, \& Handa, 2013). Di samping itu organisasi rumah sakit sebagai pemberi pelayanan kesehatan harus mampu menerima keselamatan sebagai nilai baru dalam budaya organisasi dengan komitmen berani berubah, berubah dalam arti blaming cultur menjadi safety cultur (Cahyono, 2008).

$$
\text { Budaya keselamatan pasien }
$$
dikatakan berhasil apabila semua elemen yang ada didalam rumah sakit menerapkan budaya keselamatan pasien dalam pekerjaannya sehari-hari (Reiling, 2009). Sedangkan Beginta (2012) mengatakan bahwa upaya yang dapat dilakukan untuk meningkatkan budaya keselamatan adalah dengan mendorong setiap orang bertanggung jawab akan keselamatan terhadap diri sendiri, rekan kerja, pasien, dan pengunjung, mengutamakan keselamatan dan keuntungan di atas keutungan dan tujuan organisasi.

Budaya keselamatan pasien merupakan langkah utama dalam meningkatkan keselamatan pasien. Pemimpin merupakan motor penggerak untuk melakukan aktifitas sesuai dengan yang diharapkan organisasi. Promosi budaya keselamatan pasien yang baik merupakan pelaksanaan dari intervensi yang mendasar dari kepemimpinan yang akan merubah perilaku anggota tim(Weaver et al., 2013).

Menurut PMK Nomor 1691 tahun 2011 menjelaskan bahwa membangun kesadaran akan nilai keselamatan pasien, memimpin dan mendukung staf dalam penerapan keselamatan pasien merupakan bagian penting dalam meciptakan budaya keselamatan pasien.

Membangun budaya keselamatan pasien dirumah sakit diperlukan manajemen rumaah sakit terutama peran pemimpin rumah sakit. Dukungan tersebut dapat berupa pembentukan dan penerapan program-program keselamatan pasien, pelatihan-pelatihan yang berkaitan dengan keselamatan pasien, penyedia sarana prasarana. 
3. Dimensi Budaya Keselamatan Pasien

Distribusi budaya keselamatan pasien

di ruang Instalasi Perawatan Intensive

RSUD Arifin Achmad Provinsi Riau sebagai berikut:

Tabel 3 Distribusi Frekuensi Dimensi Budaya Keselamatan Pasien $(n=64)$

\begin{tabular}{llrrr}
\hline No & \multicolumn{1}{c}{ Variabel } & Mean & Negatif & Positif \\
\hline 1 & $\begin{array}{l}\text { Kerjasama tim } \\
\text { dalam unit di }\end{array}$ & 12.36 & 60.9 & 39.1 \\
& Rumah Sakit & & & \\
\hline 2 & $\begin{array}{l}\text { Kerjasama antar } \\
\text { unit di rumah } \\
\text { sakit }\end{array}$ & 9.94 & 21.9 & 78.1 \\
\hline 3 & $\begin{array}{l}\text { Dimensi } \\
\text { Pembelajaran } \\
\text { organisasi }\end{array}$ & 12.45 & 57.8 & 42.2 \\
\hline 4 & $\begin{array}{l}\text { Umpan balik } \\
\text { dari supervisor }\end{array}$ & 12.28 & 50 & 50 \\
\hline 5 & Staffing & 6.14 & 67.2 & 32.8 \\
\hline 6 & $\begin{array}{l}\text { Komunikasi } \\
\text { Terbuka }\end{array}$ & 11.79 & 79.7 & 20.3 \\
\hline 7 & Pelaporan & 10.41 & 43.8 & 56.3 \\
\hline 8 & $\begin{array}{l}\text { Persepsi } \\
\text { terhadap } \\
\text { keselamatan } \\
\text { pasien }\end{array}$ & 10.91 & 62.5 & 37.5 \\
\hline 9 & Operan & 9.56 & 45.3 & 54.7 \\
\hline 10 & $\begin{array}{l}\text { Respon tidak } \\
\text { menghukum } \\
\text { terhadap } \\
\text { kesalahan }\end{array}$ & 9.17 & 42.2 & 57.8 \\
\hline 11 & $\begin{array}{l}\text { Dukungan } \\
\text { manajemen } \\
\text { rumah sakit }\end{array}$ & 11.86 & 68.8 & 31.3 \\
\hline 12 & $\begin{array}{l}\text { Harapan } \\
\text { supervisor }\end{array}$ & 12.08 & 54.7 & 45.3 \\
\hline & & & \\
\hline
\end{tabular}

Berdasarkan tabel 3 maka terlihat bahwa dari 12 dimensi budaya keselamatan pasien yang ada pada Instalasi Perawatan Intensif RSUD Arifin Achmad Provinsi Riau bahwa 7 dimensi budaya keselamatan pasien berada pada kategori negative yaitu pada dimensi kerjasama tim dalam unit (60.9\%), dimensi pembelajaran organisasi
(57.8\%), dimensi staffing (67.2\%), dimensi komunikasi terbuka (79.7\%), dimensi persepsi terhadap keselamatan pasien (62.5\%), dimensi dukungan manajemen rumah sakit serta harapan supervisor terhadap keselamatan pasien (68.8\%) sedangkan 5 dimensi budaya keselamatan pasien dalam kategori positif yaitu dimensi kerjasama antar unit di rumah sakit (78.1\%), dimensi umpan balik dari supervisor (50\%), dimensi pelaporan $(56.3 \%)$, dimensi operan (54.7\%) dan dimensi respon tidak menghukum terhadap kesalahan (57.3\%)

Kerjasama tim dalam rumah sakit merupakan salah satu factor yang mendukung terbentuknya budaya keselamatan pasien. Menurut (Top \& Tekingunduz, 2014). Hasil penelitian pada dimensi kerjasana tim dalam unit dengan kategori negatif yaitu $60.9 \%$. Aspek kerja sama ini dapat menjadi indikasi adanya budaya keselamatan pasien yang negatif.

Hasil penelitian budaya keselamatan pasien dimensi kerja sama dalam unit bertolok belakang dengan hasil penelitian budaya keselamatan pasien pada diemnsi kerja sama antar uni dalam rumah sakit. Hasil penelitian tersebut sejalan dengan hasil penelitian Najjar, Nafouri, Vanhaecht dan Euwema (2015) di Rumah Sakit Palestina menunjukkan bahwa budaya keselamatan pasien pada dimensi tim kerja perawat antara unit 
dalam rumah sakit dalam ketegori positif 73\%. Menurut peneliti kerja sama tim yang telah terbentuk disebuah organisasi tidak terlepas dari adanya dukungan dari organisasi serta sistem yang terdapat dalam sebuah organisasi. Pihak manajemen rumah sakit memiliki peran penting untuk meningkatkan sebuah tim yang solid dalam pemberian pelayanan keperawatan.

Hasil penelitian juga memperlihatkan bahwan budaya keselamatan pasien perawat pada dimensi pemebelajaran organisasi dalam kategori negative yaitu sebesar 57.8\%. (Reiling, 2009) mengatakan bahwa budaya pembelajaran terbentuk ketika individu belajar dari kesalahan dan mampu meningkatkan kemampuan sebagai bagian dari sistem pembelajaran. Dimulai ketika pemimpin menjadi role model bagi serta adanya peran serta setiap lini dalam organisasi, baik perawat maupun manajemen menggunakan insiden yang terjadi sebagai proses belajar.

Perawat dan manajemen berkomitmen untuk mempelajari kejadian yang terjadi. Mengambil tindakan atas kejadian tersebut untuk diterapkan sehingga dapat mencegah terulangnya kesalahan. Adanya umpan balik dari organisasi dan rekan satu tim merupakan suatu bentuk dari pembelajaran organisasi. Hal ini tergambar pada hasil penelitian pada dimensi umpan balik dari supervisor bahwasanya $50 \%$ berada dalam kateori negative dan $50 \%$ dalam kategori positif. Dengan demikian adanya umpan balik dalam organisasi sangat di butuhkan dalam meningkakan budaya keselamatan pasien di RSUD Arifin Achmad Provinsi Riau.

Berdasarkan hasil penelitian $67.2 \%$ perawat memiliki budaya keselamatan negatif pada dimensi ketenagaan atau staffing yang berkaitan dengan Sumber Daya Manusia pada Instalasi Perawatan Intensive RSUD Arifin Achmad Provinsi Riau. Adanya beban kerja yang tinggi, kelebihan jam kerja merupakan hal yang dapat mempengaruhi budaya keselamatan pasien pada perawat. Hal ini sejalan dengan hasil penelitian El-jardali di rumah sakit Riyadh (Najjar et al., 2015a) $64.9 \%$ perawat yang memiliki budaya keselamatan negatif yang berkaitan dengan beban kerja yang tinggi (ElJardali et al., 2014). (Nie et al., 2013) dalam penelitiannya diperoleh hasil bahwa $51.0 \%$ perawat di Amerika Serika mengatakan mengalami kelebihan jam kerja di ruangan.

Staffing tidak hanya diartikan sebagai jumlah ketenagaan yang terdapat di ruangan, namun adanya kesesuaian penempatan ketenagaan berdasarkan kebutuhan ruangan berdasarkan kompetensi perawat juga merupakan poin dalam manajemen ketenagaan. (Beginta, 2012) mengatakan bahwa staffing 
merupakan proses penempatan pekerja yang ahli untuk mengisi struktur organisasi melalui seleksi dan pengembangan personel. Jumlah perawat di rumah sakit mempengaruhi kualitas pelayanan yang diterima pasien di rumah sakit

Hasil penelitan juga memperlihatkan bahwa budaya keselamatan pasien pada dimensi komunikasi terbuka dan persepsi terhadap keselamatan berada dalam kategori negative yaitu $79.7 \%$ dan $62.5 \%$. Budaya keselamatan pasien yang positif mempunyai ciri-ciri yaitu terdapatnya komunikasi yang dibangun harus berdasarkan keterbukaan, diketahui oleh seluruh pegawai dan mencerminkan tentang keselamatan pasien. Disamping itu komunikasi terbuka merupakan salah satu komponen dari budaya keselamatan pasien.

Penelitian tentang budaya keselamatan pasien yang dilakukan oleh (Nie et al., 2013) diperoleh hasil bahwa $53 \%$ perawat memiliki budaya keselamatan pasien negatif pada poin komunikasi terbuka hal ini tergambar pada jawaban responden merasa takut mengajukan pertanyaan jika melihat terjadinya KTD disekitar mereka. Dengan demikian komunikasi yang baik yang dilakukan diantara perawat di Intalasi Perawatan Intensive RSUD Arifin Achmad dapat meningkatkan kemampuan perawat dalam melakukan tindakan yang berkaitan dengan keselamatan pasien.

Hasil penelitian budaya keselamatan pasien juga memperlihatkan bahwa dukungan manajemen rumah sakit dan harapan supervisor dalam kategori budaya negatif. Hasil penelitian ini tentunya tidak terlepas dari adanya dukungan manajemen dalam mempromosikan budaya keselamatan pasien. Dimana menurut (Weaver et al., 2013) mengatakan bahwa mempromosikan budaya keselamatan pasien merupakan langkah utama dalam meningkatkan keselamatan pasien. Pemimpin merupakan motor penggerak untuk melakukan aktifitas sesuai dengan yang diharapkan organisasi.

Pemimpin merupakan motor penggerak untuk melakukan aktifitas sesuai dengan yang diharapkan organisasi. Promosi budaya keselamatan pasien yang baik merupakan pelaksanaan dari intervensi yang mendasar dari kepemimpinan yang akan merubah perilaku anggota tim. Sedangkan menurut (Nivalinda et al., 2013) Budaya keselamatan yang kuat membutuhkan kepemimpinan yang mampu menetapkan dan mengkomunikasikan visi keselamatan dengan jelas, menghargai dan memberdayakan staf untuk mencapai visi keselamatan pasien.

Budaya keselamatan pasien positif yang ditunjukkan oleh perawat di 
Instalasi Perawatan Intensif RSUD Arifin

Achmad Provinsi riau adalah pada dimensi pelaporan dan operan. Dimana hasil penelitian pada budaya keselamatan pada dimensi operan berjumlah $56.3 \%$ dalam kategori positif dan $54.7 \%$ pada dimensi Handove atau operan. Menurut (Jeffs, Law, \& Gr, 2007) pelaporan merupakan unsur penting dari keselamatan pasien. Informasi yang adekuat pada pelaporan akan dijadikan bahan oleh organisasi dalam pembelajaran. Organisasi belajar dari pengalaman sebelumnya dan mempunyai kemampuan untuk mengidentifikasi faktor risiko terjadinya insiden sehingga dapat mengurangi atau mencegah insiden yang terjadi.

Menurut (Hamdani, 2007) transisi merupakan proses berpindahnya pasien dari satu lingkungan ke lingkungan lain. Dalam perpindahan tersebut dapat terjadi suatu kesalahan sehingga membahayakan pasien seperti jatuhnya pasien dan kesalahan informasi ketika terjadi pertukaran informasi mengenai pasien. Kesalahan informasi mengenai pasien tersebut juga dapat terjadi ketika berlangsungnya pergantian shift antar perawat.

Berdasarkan hasil penelitian dan teori maka kesalahan informasi tersebut dapat dipengaruhi oleh berbagai faktor penyabab diantaranya kesiapan perawat pada saat pertukaran informasi serta fokus perhatian perawat pada saat pertukaran informasi memiliki peranan penting. Kesiapan dan fokus perawat tersebut pada dasarnya dapat berkaitan dengan adanya beban kerja yang tinggi yang menyebabkan kelelahan perawat sehingga mempengaruhi perkembangan budaya keselamatan pasien.

\section{KESIMPULAN DAN SARAN}

\section{Kesimpulan}

Berdasarkan hasil penelitian di dapatkan bahwa $56.3 \%$ perawat di Instalasi Perawatan Intensif RSUD Arifin Achmad Provinsi Riau memiliki budaya keselamatan negatif dengan karakteristik responden yang bervariasi baik usia, jenis kelamin, pendidikan dan lama kerja yang memungkinkan berpengaruh terhadap budaya keselamatan pasien pada perawat.

\section{Saran}

Berdasarkan hasil penelitiani maka perlu adanya program-program keselamatan pasien yang di laksanakan oleh menajemen rumah sakit pada pelayanan keperawatan untuk mendorong terbentuknya budaya keselamatan pasien di rumah sakit.

\section{DAFTAR PUSTAKA}

AHRQ. (2016). AHRQ Hospital Survey on Patient Safety Culture: User's Guide.

Amarapathy, M., Sridharan, S., Perera, R., \& Handa, Y. (2013). Factors Affecting Patient Safety Culture In A Tertiary Care Hospital In Sri Lanka. 2(3), 173-179. 
Anwar, Z. (2018). Mentoring sebagai suatu inovasi dalam peningkatan kinerja. Jurnal of Education and Instruction, 1(1), 21-28.

Aspend. (2017). Preventing Medication Errors : Quality Chasm Series .

Beginta, R. (2012). Pengaruh budaya..., Romi beginta, FKMUI, 2012. In pengaruh budaya keselamatan pasien, gaya kepemimpinan, tim kerja, terhadap persepsi pelaporan kesalahan pelayanan oleh perawat di unir Rawat Inap Rumah sakit Umum Daerah Kabuaten Bekasi.

Budihardjo, A. (2008). Safety Culture. In Pentingnya Safty Culture di Rumah Sakit (pp. 53-69).

Cahyono. (2008). membangun budaya keselamatan pasien dalam praktik kedokteran. Yogyakarta: Kanisius.

El-Jardali, F., Sheikh, F., Garcia, N. A., Jamal, D., \& Abdo, A. (2014). Patient safety culture in a large teaching hospital in Riyadh: Baseline assessment, comparative analysis and opportunities for improvement. BMC Health Services Research, 14. https://doi.org/10.1186/1472-696314-122

Hamdani, S. (2007). Analisis budaya keselamatan pasien ( patient safety culture ) ri Rumah Sakit Islam Jakarta tahun 2007 / Siva Hamdani. 95-97.

Hammer, A., Ernstmann, N., Ommen, O., Wirtz, M., Manser, T., \& Pfeiffer, Y. (2011). Psychometric properties of the Hospital Survey on Patient Safety Culture for hospital management ( HSOPS _ M ). BMC Health Services Research, 11(1), 165. https://doi.org/10.1186/14726963-11-165

Jeffs, L., Law, M., \& Gr, B. (2007). Creating reporting and learning cultures in health - care organizations . National Library in Madicine, 17410924.

KKPRS. (2015). Pedoman pelaporan insiden keselamatan pasien (ikp). In Pedoman Pelaporan Insiden Keselamatan Pasien (IKP) (pp. 1-
56).

Najihah. (2018). Budaya Keselamatan Pasien Dan Insiden Keselamatan Pasien Di Rumah Sakit: Literature Review. Journal of Islamic Nursing, 3(1), 1.

Najjar, S., Nafouri, N., Vanhaecht, K., \& Euwema, M. (2015a). The relationship between patient safety culture and adverse events : a study in palestinian hospitals. Safety in Health, 1 (December). https://doi.org/10.1186/s40886-0150008-z

Najjar, S., Nafouri, N., Vanhaecht, K., \& Euwema, M. (2015b). The relationship between patient safety culture and adverse events: a study in palestinian hospitals. Safety in Health, 1(1), 1-9. https://doi.org/10.1186/s40886-0150008-Z

Nie, Y., Mao, X., Cui, H., He, S., Li, J., \& Zhang, M. (2013). Hospital survey on patient safety culture in China. Retrieved from http://www.biomedcentral.com/147 2-6963/13/228\%0APage

Nivalinda, D., Hartini, M. C. I., \& Santoso, A. (2013). pengaruh motovasu perawat dan gaya kepemimpinan kepala ruangan terhadap penerapan budaya keselamatan pasien oleh perawat pelaksana pada rumah sakit pemerintah di semarang. Jurnal Manajemen Keperawatan, 1(2), 138-145.

Nurmalia, D. (2013). Pengaruh program mentoring terhadap penerapan budaya keselamatan pasien. Jurnal Manajemen Keperawatan, 1(2), 7988.

Reiling, J. G. (2009). Creating a Culture of Patient Safety through Innovative Hospital Design. In Patient safety (pp. 425-440).

Top, M., \& Tekingunduz, S. (2014). Patient Safety Culture in a Turkish Public Hospital : A Study of Nurses 'Perceptions About Patient Safety.

Weaver, S. J., Lubomksi, ILsa H., Wilson, R. F., Elizabeth, Martinez, 
K. A., \& Sydney. (2013). Annals of Internal Medicine Supplement Promoting a Culture of Safety as a Patient Safety Strategy. Annals of Internal Medicine, 158(5).

Webair, H. H., Al-assani, S. S., Alhaddad, R. H., Al-shaeeb, W. H., Selm, M. A. Bin, \& Alyamani, A. S. (2015). Assessment of patient safety culture in primary care setting, Al-Mukala, Yemen. BMC Family $\quad$ Practice, 136. https://doi.org/10.1186/s12875-0150355-1 